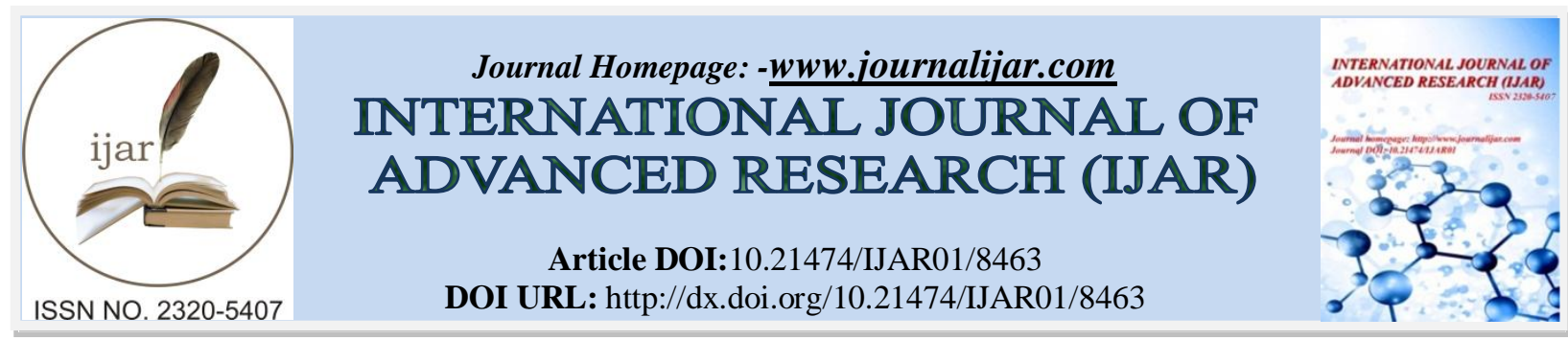

RESEARCH ARTICLE

\title{
BALANCE DISORDERS DUE TO PESTICIDE EXPOSURE IN FARMERS WOMEN IN BANDUNGAN SUB-DISTRICT, SEMARANG DISTRICT.
}

ShalihatAfifah Dhaningtyas ${ }^{1}$, Onny Setiani ${ }^{2}$ AndNurjazuli ${ }^{2}$.

1. Students in the Environmental Health Master's Program at the Faculty of Public Health, Diponegoro University.

2. Teaching Staff for Environmental Health Master's Program at the Faculty of Public Health, Diponegoro

University.

\section{Manuscript Info}

\section{Manuscript History}

Received: 02 December 2018

Final Accepted: 04 January 2019

Published: February 2019

Key words:-

pesticides, women farmers, balance disorders.

\begin{abstract}
In the development of the agricultural sector, increasing use of pesticides also occurs in almost all agriculture in Indonesia, especially on the island of Java. Acute poisoning because pesticides are a problem in all countries. Estimated number of cases per year is 1-3 million. Mortality rates ranging from $1 \%$ to $9 \%$ of cases who come for treatment. Most cases of accidental pesticide poisoning are among farmers and farmer families. The study aimed to analyze the relationship of pesticide exposure to balance disorders in farmerswomen in Bandungan Sub-district, Semarang District. This research was observational type with cross sectional design. The sampling technique was nonprobability sampling with purposive sampling. The number of samples in this study were 50 farmerswomen. The results of this study that there were a correlation between cholinesterase levels $(p=0.016), \mathrm{RP}=3.865(\mathrm{CI}) 95 \%=$ 1.051-14.214, working period $(p=0.049), \mathrm{RP}=1.957$ (CI) $95 \%=$ 1.062 - 3.605with balance disorders in farmerswomen in Bandungan Sub-district, Semarang District.There was no correlation betweenpesticide dose $(p=0.839), \mathrm{RP}=1.165(\mathrm{CI}) 95 \%=0.65-2.088$ with balance disorders in farmerswomen in BandunganSub-district, Semarang District. The conclusion of the researchthat there were correlation between cholinesterase levels, working periodwith balance disorders in farmerswomen in BandunganSub-district, Semarang District. There was no correlation betweenthe pesticidedosewith balance disorders in farmerswomen in BandunganSub-district, Semarang District.
\end{abstract}

Copy Right, IJAR, 2019,. All rights reserved.

Introduction:-

Indonesia is an agricultural country where the role of the agricultural sector becomes dominant in the national economic system. In the development of the agricultural sector, increasing use of pesticides also occurs in almost all agriculture in Indonesia, especially on the island of Java. Pesticide residues from several types of pesticides such as organochlorine, organophosphate, and carbamatewere found in vegetable plants. Pesticide residue analysis on red chili in Bandungan, Central Java Province was found in dieldrin residues, heptachlor EP, endosulfan, chlorpyrifos, malation. Pesticide residue analysis on lettuce in Bandungan, Central Java Province was found in aldrin residues,

Corresponding Author:-ShalihatAfifahDhaningtyas.

Address:-Students in the Environmental Health Master's Program at the Faculty of Public Health, 
heptachlor EP, endosulfan, chlorpyrifos, profenofos, karbaril.(Miskiyah and Munarso,2008)The study aimed to analyze the relationship of pesticide exposure to balance disorders in farmerswomen in Bandungan Sub-district, Semarang District.

\section{Literature Review:- \\ Pesticide:-}

Based on the Decree of the Minister of Agriculture of the Republic of Indonesia Number 434.1 / Kpts / TP.270 / $7 / 2001$ concerning the requirements and procedures for registering pesticides, pesticides are all chemical substances, microorganisms and viruses used to eradicate pests and diseases that damage crops, eradicate grasses, pests in domestic animals and livestock, water pests, animals and microorganisms in households, buildings, and in transportation equipment, animals which cause disease in humans.(Pertanian,2012)According to The United States Environmental Control Act, pesticides are a mixture of special substances to dispel insecticides, control, prevent rodents, bacteria, viruses, weeds, nematodes, microorganisms that are considered pests except bacteria, viruses or other microorganisms found in animals and human.

\section{Human Body Balance System:-}

Balance is the ability to maintain the orientation of the body and parts of the body in relation to the surrounding environment. The balance depends on the continuous input of the three systems, namely the vestibular (labyrinth), proprioceptive (somatosensory) system, visual and its integration with the brain stem and cerebellum. (Sutarni et al.,2018)

\section{Risk Factors for Balance Disorders:-}

The risk factors for balance disorders were age(Sihvonen,2004), gender(Sihvonen,2004)(Lord et al.,2007), occupational (Gauchard et al.,2003), neurological disorders(Brooke Salzman,2010), physical activity(Rodgers,2018), sensory disorders(Brooke Salzman,2010), musculoskeletal disorders(Brooke Salzman,2010), infectious disease and metabolic disorders(Brooke Salzman,2010), affective disorders and psychiatric conditions(Brooke Salzman,2010), use of road aids(Cordeiro et al.,2009), foot disorders(Skelton and Todd,2004), frequency of use of drugs related to falls.(Moylan and Binder,2007)

\section{Vestibular Tests:-}

Vestibular tests that can be done, namelynystagmus, Spontaneous nystagmus examination begins with a person staring straight, then the person is asked to move his gaze at $30^{\circ}$ to the left and right. Each position is given a minimum of 15 seconds. Nystagmus is identified directly. If the person moves the eye to the right, left, up, down with a different speed (jerk nystagmus) continuously in 1 or more than 3 positions in a consistent direction, then the test results are positive vestibular nystagmus; romberg test,Examination that begins with a person standing straight, both hands beside the body, both feet closed tightly, and eyes closed for 30 seconds. If there is a lot of shake or loss of balance, the test results are positive.Romberg tests involve vision and depend on accurate vestibular sensory information and cerebellar function. In the vestibular schwannoma, a positive Romberg test result is caused by a disruption of the vestibular signal; unterburger's stepping test,An examination that begins with someone standing upright with their eyes closed and arms stretched $90^{\circ}$ with the body, and knees lifted alternately, thigh reaches a horizontal position (walking in place). If the person rotates more than $30^{\circ}$, shakes, and falls, then the test results are positive;tandem gait, An examination that begins with someone walking using the heel in a straight line with their eyes open and eyes closed. There is no standard distance, but the test continues until the person shows good results. If the person is rocking or falling, the test results are positive.(Beynon et al.,1995) 


\section{Research model:-}
Independent Variable:
1. Cholinesterase level
2. Working period
3. Dose of pesticide

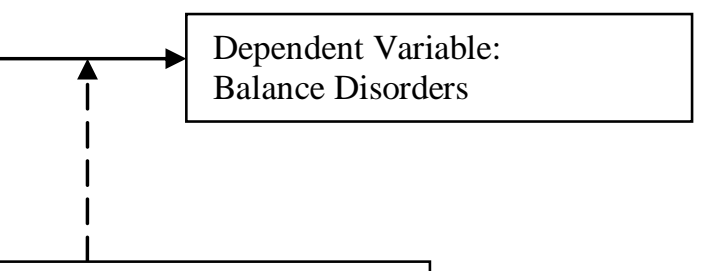

\section{Confounding:}

1. Physical activity

2. Use of drugs

3. Use of PPE (personal protective equipment)

4. Personal and social history

5. Pesticide storage

\section{Research hypotheses:-}

1. H1 There is a correlation between cholinesterase levels and balance disorders in farmers women in Bandungan Sub-district, Semarang District.

2. H2 There is a relationship between the working period and balance disorders in farmerswomen in Bandungan Sub-district, Semarang District.

3. H3 There is a relationship between the pesticides dose and balance disorders in farmerswomen in Bandungan Sub-district, Semarang District.

\section{Methodology:-}

This research was observational type with cross sectional design. The sampling technique was nonprobability sampling with purposive sampling. The number of samples in this study were 50 farmerswomen.

\section{Data Analysis:-}

\section{Background Information:-}

Table 1:-Characteristics of Women Farmers in Bandungan District, Semarang District

\begin{tabular}{|r|l|c|c|c|c|c|c|}
\hline No & \multicolumn{1}{|c|}{ Variable } & Frequency & Minimum & Maximum & Mean & Median & $\begin{array}{c}\text { Standard } \\
\text { Deviation }\end{array}$ \\
\hline 1 & $\begin{array}{l}\text { Age of } \\
\text { respondent(years) }\end{array}$ & 50 & 21 & 63 & 39,2 & 39,5 & 10,55 \\
\hline 2 & Height (cm) & 50 & 138 & 158 & 148,78 & 148 & 4,268 \\
\hline 3 & Weight (kg) & 50 & 44 & 89 & 62,284 & 61 & 11,6885 \\
\hline 4 & $\begin{array}{l}\text { Cholinesterase level } \\
\text { (U / L) }\end{array}$ & 50 & 4041 & 9384 & 6656,94 & 6901 & 1538,369 \\
\hline 5 & $\begin{array}{l}\text { Working period } \\
\text { (years) }\end{array}$ & 50 & 1 & 35 & 16,82 & 18 & 10,022 \\
\hline 6 & $\begin{array}{l}\text { Dosage as } \\
\text { recommended }\end{array}$ & $34 \%$ & & & & & \\
\hline & No & $66 \%$ & & & & & \\
\hline 7 & Yes & $74 \%$ & & & & & \\
\hline & Abnolinesterase levels & $26 \%$ & & & & & \\
\hline & Normal & & & & & & \\
\hline & Balance disorders & Yes & $48 \%$ & & & & \\
\hline
\end{tabular}




\begin{tabular}{|l|l|l|l|l|l|l|}
\hline & No & $52 \%$ & & & & \\
\hline
\end{tabular}

\section{Chi Square Analysis:-}

Table 2:- Relationship between Cholinesterase Levels and Balance Disorders in Farmer Women in Bandungan District, Semarang District

\begin{tabular}{|c|c|c|c|c|c|c|c|c|}
\hline \multirow[t]{3}{*}{ No } & \multirow{3}{*}{$\begin{array}{c}\text { Cholinesterase } \\
\text { Levels }\end{array}$} & \multicolumn{4}{|c|}{ Balance Disorders } & \multirow{2}{*}{\multicolumn{2}{|c|}{ Total }} & \multirow[t]{3}{*}{$\mathrm{p}$ value } \\
\hline & & \multicolumn{2}{|c|}{ Yes } & \multicolumn{2}{|l|}{ No } & & & \\
\hline & & Frequency & Percent & Frequency & Percent & Frequency & Percent & \\
\hline 1 & Abnormal & 22 & 59,5 & 15 & 40,5 & 37 & 100 & \multirow[t]{2}{*}{0,016} \\
\hline 2 & Normal & 2 & 15,4 & 11 & 84,6 & 13 & 100 & \\
\hline \multicolumn{4}{|c|}{$\mathrm{RP}=3,865$} & \multicolumn{2}{|c|}{$95 \% \mathrm{CI}=1,051-14,214$} & & & \\
\hline
\end{tabular}

Table 3:- Relationship between Working Period and Balance Disorders in Farmer Women in Bandungan District, Semarang District

\begin{tabular}{|c|c|c|c|c|c|c|c|c|}
\hline \multirow[t]{3}{*}{ No } & \multirow{3}{*}{$\begin{array}{l}\text { Working period } \\
\text { (years) }\end{array}$} & \multicolumn{4}{|c|}{ Balance Disorders } & \multirow{2}{*}{\multicolumn{2}{|c|}{ Total }} & \multirow[t]{3}{*}{$\mathrm{p}$ value } \\
\hline & & \multicolumn{2}{|c|}{ Yes } & \multicolumn{2}{|c|}{ No } & & & \\
\hline & & Frequency & Percent & Frequency & Percent & Frequency & Percent & \\
\hline 1 & $>18$ years & 15 & 65,2 & 8 & 34,8 & 23 & 100 & \multirow[t]{2}{*}{0,049} \\
\hline 2 & $\leq 18$ years & 9 & 33,3 & 18 & 66,7 & 27 & 100 & \\
\hline \multicolumn{4}{|c|}{$\mathrm{RP}=1,957$} & \multicolumn{2}{|c|}{$95 \% \mathrm{CI}=1,062-3,605$} & & & \\
\hline
\end{tabular}

Table 4:- Relationship between Dose of Pesticides and Balance Disorders in Farmer Women in Bandungan District, Semarang District

\begin{tabular}{|c|c|c|c|c|c|c|c|c|}
\hline \multirow[t]{3}{*}{ No } & \multirow{3}{*}{$\begin{array}{c}\text { Dose of } \\
\text { Pesticides }\end{array}$} & \multicolumn{4}{|c|}{ Balance Disorders } & \multirow{2}{*}{\multicolumn{2}{|c|}{ Total }} & \multirow[t]{3}{*}{$\mathrm{p}$ value } \\
\hline & & \multicolumn{2}{|c|}{ Yes } & \multicolumn{2}{|l|}{ No } & & & \\
\hline & & Frequency & Percent & Frequency & Percent & Frequency & Percent & \\
\hline 1 & $\begin{array}{l}\text { Not in } \\
\text { accordance } \\
\text { with advice }\end{array}$ & 9 & 52,9 & 8 & 47,1 & 17 & 100 & 0,839 \\
\hline 2 & $\begin{array}{r}\text { As } \\
\text { recommended }\end{array}$ & 15 & 45,5 & 18 & 54,5 & 33 & 100 & \\
\hline
\end{tabular}

\section{Discussion:-}

Anti-ChE agents can potentially produce all of the following effects: 1. stimulation of muscarinic receptor responses in autonomous effector organs; 2. stimulation, followed by depression or paralysis, of all autonomic ganglia and skeletal muscles (nicotinic action); and 3. stimulation, with occasional depression, from cholinergic receptors in the central nervous system.(Brunton,2006). Exposure to pesticides with heterogeneous chemical structures can cause different health effects. Short and medium term OP (organophosphate) exposure is mainly associated with liver damage and peripheral nerve disorders, while OS (organosulfur) exposure can cause liver damage and kidney dysfunction. Neurotoxicity resulting from exposure to ON (organonrogen) after OP exposure (organophosphate) in addition to potential liver damage and induced glucose changes. In comparison, the estimation results show that PYR (piretroid) may be the most toxic in the case of low dose use.(Huang et al.,2016). The toxicity of chemicals depends on the nature of the poison, the pathway of exposure (oral, dermal and inhalation), dosage and morphology and psychology of the state of the organism. Pesticide toxicity is usually expressed in the form of LD50 or LC50. This value is expressed in milligrams per kilogram of body weight or each ppm.(Singh,2012).

\section{Conclusion:-}

There was a correlation between cholinesterase levels and balance disorders in farmerswomen in BandunganSubdistrict, Semarang District. There was a relationship between the working period and balance disorders in farmerswomen in BandunganSub-district, Semarang District.There was no relationship between pesticide doses and balance disorders in farmers women in BandunganSub-district, Semarang District. 


\section{Recommendations:- \\ For Policy and Practice:-}

For the government to actively carry out supervision of pesticides and cooperate across sectors such as the Agriculture, Industry, Trade, Health, Food and Drug Supervisory Agency, Manpower and Transmigration, Marine and Fisheries, Forestry, Environment and others.

For farmers to implement procedures for the use of pesticides in accordance with the rules, carry out periodic and routine health tests (blood tests, blood pressure, urine) to monitor health.

\section{References:-}

1. Ardiwinata, a. N. \&nursyamsi, d. 2012. Residupestisida di sentraproduksipadi di jawatengah. Pangan, 21.

2. Brunton, 1. L. (ed.) 2006. Goodman \&gilman's : the pharmacological basis of therapeutics, united states of america: mcgraw-hill medical publishing division.

3. Huang, x., zhang, c., hu, r., li, y., yin, y., chen, z., cai, j. \& cui, f. 2016. Association between occupational exposures to pesticides with heterogeneous chemical structures and farmer health in china scientific reports 6.

4. Singh, d. K. 2012. Toxicology : agriculture and environment. Delhi: benthamebooks.

5. Sutarni, s., malueka, r. G. \&gofir, a. 2018. Bungarampai vertigo, yogyakarta, gadjahmada university press.

6. Beynon, G. J., Baguley, D. M. \& Moffat, D. A. Clinical tests of vestibular function in vestibular schwannoma. In: Sterkers, J. M., Charachon, R. \& Sterkers, O., eds. Proceedings of the 2nd international conference on acoustic neuroma and 2nd european skull base, 1995 France. Kugler, 87.

7. Brooke Salzman, M. 2010. Gait and balance disorders in older adults American Family Physician, 82, 61-68.

8. Brunton, L. L. (ed.) 2006. Goodman \& Gilman's : the pharmacological basis of therapeutics, United States of America: McGraw-Hill Medical Publishing Division.

9. Cordeiro, R. C., Jardim, J. R., Perracini, M. R. \& Ramos, L. R. 2009. Factors associated with functional balance and mobility among elderly diabetic outpatients. Arq Bras Endocrinol Metab, 53, 834-843.

10. Gauchard, G. C., Chau, N., Touron, C., Benamghar, L., Dehaene, D., Perrin, P. \& Mur, J.-M. 2003. Individual characteristics in occupational accidents due to imbalance: a case-control study of the employees of a railway company Occup Environ Med, 60, 330-335.

11. Huang, X., Zhang, C., Hu, R., Li, Y., Yin, Y., Chen, Z., Cai, J. \& Cui, F. 2016. Association between occupational exposures to pesticides with heterogeneous chemical structures and farmer health in china Scientific Reports 6, 1-7.

12. Lord, S., Sherrington, C., Menz, H. \& Close, J. 2007. Falls in older people New York, Cambridge University Press.

13. Miskiyah \& Munarso, S. J. 2008. Kontaminasi residu pestisida pada cabai merah, selada, dan bawang merah (studi kasus di bandungan dan brebes jawa tengah serta cianjur jawa barat). Jurnal Hortikultura, 19, 101-111.

14. Moylan, K. C. \& Binder, E. F. 2007. Falls in older adults : risk assessment, management and prevention. The American Journal of Medicine, 120.

15. Pertanian, D. J. P. d. S. 2012. Pedoman teknis kajian pestisida terdaftar dan beredar ta.2012. Direktorat Pupuk dan Pestisida Kementerian Pertanian.

16. Rodgers, A. B. 2018. Exercise \& physical activity National Institute on aging.

17. Sihvonen, S. 2004. Postural balance and aging : cross-sectional comparative studies and a balance training intervention. University of Jyväskylä.

18. Singh, D. K. 2012. Toxicology : agriculture and environment. Delhi: Bentham eBooks.

19. Skelton, D. \& Todd, C. 2004. What are the main risk factors for falls amongst older people and what are the most effective interventions to prevent these falls? . WHO.

20. Sutarni, S., Malueka, R. G. \& Gofir, A. 2018. Bunga rampai vertigo, Yogyakarta, Gadjah Mada University Press. 